\title{
Cytogenetic and reproductive studies of bulls born co-twin with freemartins
}

\author{
H. O. Dunn, K. McEntee, C. E. Hall, R. H. Johnson, Jr \\ and W. H. Stone* \\ New York State College of Veterinary Medicine, Ithaca, New York 14853 and \\ *Laboratory of Genetics, University of Wisconsin, Madison, Wisconsin 53706, U.S.A.
}

\begin{abstract}
Summary. The XX lymphocytes in peripheral blood of 22 bulls born co-twin with freemartins ranged from 5 to $95 \%$. The difference of $1.2 \%$ between the means of XX percentages at initial and final karyotyping of 14 bulls over periods of $1-5$ years was not significant $(P>0.25)$. Seven $(58.3 \%)$ of the 12 A.I. chimaeric bulls were reproductive culls as compared to only $5.4 \%$ of their 128 controls $(P<0.001)$. The culled chimaeras produced no semen, had a low sperm output or had a high incidence of abnormal spermatozoa. The means for motility, sperm concentration and motile spermatozoa per ejaculate were significantly lower for the 12 chimaeric bulls than for a random sample of 12 controls $(P<0.025)$. The 60 - to 90-day nonreturn rate for 30814 services to 8 chimaeric bulls was $70 \%$ with a $-0.1 \%$ mean deviation from contemporary breed average $(P>0 \cdot 5)$.

The 7 chimaeric bulls culled for poor reproductive performance had larger and more numerous focal areas of testicular degeneration. Areas of lymphocytic infiltration in testes of many of these bulls suggest a rejection phenomenon or the autoimmune response. No XX germ cells were detected in testes of 11 chimaeric bulls, aged 1-9 years. Differential haemolysis blood typing tests on one bull with $85 \%$ XX lymphocytes and 23 of his dam-daughter pairs provided no evidence of germ cell chimaerism. One bull with $33 \% \mathrm{XX}$ cells sired an excess of daughters (71\%) in a progeny group of 48 , a significant deviation from a $1: 1$ ratio $(P<0.01)$.

A disturbance in normal spermatogenesis in prenatal and postnatal life by transplanted XX primordial germ cells may contribute to the marked reduction in reproductive fitness of many chimaeric bulls.
\end{abstract}

\section{Introduction}

The factors responsible for the virilization of the freemartin gonad have eluded discovery for over half a century (Ohno, 1969; Jost, Vigier \& Prepin, 1972). Ohno, Christian, Wachtel \& Koo (1976) have proposed that H-Y antigen, specified by a gene on the $\mathrm{Y}$ chromosome, is responsible for testicular-like transformation of the freemartin gonad.

The normality of chimaeric bulls born co-twin with freemartins went unchallenged until Ohno, Trujillo, Stenius, Christian \& Teplitz (1962) detected XX germ cells in the testes of two newborn bulls. Later, XX spermatogonia and primary spermatocytes were detected in testicular specimens from three chimaeric bulls at 2, 10 and 11 months of age (Teplitz, Moon \& Basrur, 1967). Dunn, Kenney, Stone \& Bendel (1968) then reported that $5 \mathrm{XX} / \mathrm{XY}$ bulls were either sterile or below stud average in semen quality and fertility. Other reports of a reduction in reproductive fitness of chimaeric bulls include cryptorchidism and sterility (Abdel-Raouf, 1964; Gerneke, 1969), low fertility and poor semen quality. (Stafford, 1972; de Giovanni, Popescu \& Succi, 1975; Cribiu \& Popescu, 1975), abnormal testosterone synthesis (Pierrepoint, Stewart \& 
Rack, 1969; Short et al., 1969) and underdeveloped seminal vesicles and ampullae (Short et al., 1969). Normal breeding performance of chimaeric bulls has been reported also (Hansen, 1968; Stafford, 1972; Cribiu \&-Popescu, 1975; Pollock, 1975; Gustavsson, 1977).

If transplanted XX germ cells could persist in the testes of a mature chimaeric bull and undergo meiosis as "disguised spermatocytes", there would be an increased output of X-bearing spermatozoa and an increase in the percentage of female calves in his progeny, many of which would receive genes from his freemartin twin (Ohno et al., 1962; Teplitz et al., 1967; Dunn et al., 1968).

Three chimaeric bulls are known to have sired a significantly higher number of female calves (Dunn et al., 1968; Lojda, 1972; Cribiu \& Popescu, 1975; de Giovanni et al., 1975), but there is no proof that any of these bulls had transmitted his twin sister's genes to any of his offspring via donor XX germ cells.

In the present study, observations were made on $22 \mathrm{XX} / \mathrm{XY}$ bulls to determine (1) their reproductive fitness, (2) whether donor germ cells differentiated into functional spermatogonia, and (3) the stability of the XX:XY ratios. A preliminary study of 5 of these 22 bulls has been reported previously (Dunn et al., 1968).

\section{Materials and Methods}

\section{Animals}

Thirteen chimaeric XX/XY bulls in artificial insemination (A.I.) centres and 9 in a college experimental unit were studied from 1964 to 1978 . Twelve bulls (11 Holstein and 1 Ayrshire) in the New York A.I. Centre had twin sisters. A Guernsey bull (in the Louisiana Dairy Herd Improvement Centre), registered as a singleton, was karyotyped as a chimaera following a report that $71 \%$ of his offspring were females (McSparrin \& Patrick, 1967).

For the control group, 128 non-twin bulls of the same age and breed as the 12 New York A.I. chimaeric bulls were available. Each of the 12 control units comprised 3-22 bulls. Karyotypes of 260 non-twin bulls in this centre, including 48 of the 128 controls, were $60, X Y$. Based on this large sample, all the control bulls were assumed to be non-chimaeric.

Breeding records were available on 1-2-year-old A.I. sires and on those selected on the basis of their progeny tests. No records were available on sires awaiting proofs or on sires culled with unsatisfactory proofs at 6 years of age. (Only about $2.4 \%$ of 6 -year-old bulls are culled for poor reproductive fitness.) There were no records on the 9 experimental bulls.

Semen samples with less than $50 \%$ progressively motile spermatozoa and/or less than $400 \times$ $10^{6}$ spermatozoa/ml were classified as discards. Bulls with poor libido, reproductive organ anomalies, unsatisfactory semen and low fertility were classified as reproductive culls. During the 14-year period, semen processing varied and included liquid- and frozen-semen techniques.

A comparison of reproductive fitness of chimaeric and non-chimaeric bulls was made utilizing all 128 control bulls, but for analyses of the data on semen characteristics, one bull from each control unit was selected at random for comparison with each of the chimaeric bulls. Since the sperm output of most bulls increases between 2 and 6 years of age (Coulter, Larson \& Foote, 1975), a comparison was made between the sperm production of 7 chimaeric bulls at these ages. Successive ejaculates in each age group ranged from 9 to 32 .

\section{Cytogenetic and histopathological techniques}

The leucocyte culture methods described by Dunn, Lein \& Kenney (1967) and Greene, Dunn \& Foote (1977) were used. Whenever possible at least 100 metaphases were scored to provide reliable estimates of the $\mathrm{XX}: \mathrm{XY}$ ratios which were expressed as the percentage of $\mathrm{XX}$. Each bull's code was determined by the percentage of XX cells in all metaphases examined. 
Testicular tissues were obtained from live bulls under anaesthesia or at necropsy. Colcemid was not administered to any of the bulls. Sections from the dorsal, central and ventral regions of the left and right testes were fixed in Bouin's solution for histopathological examination. Meiotic preparations were made using the techniques of Evans, Breckon \& Ford (1964) and Ohno (1965).

Differential haemolysis blood typing tests were made according to the technique of Stone, Berman, Tyler \& Irwin (1960).

\section{Results}

Blood cell cytogenetics

The XX cells in blood of the 22 chimaeric bulls ranged from 5 to $95 \%$ (Table 1). The stability of the XX:XY ratios was examined on data from 14 bulls by comparing the percentage of XX cells at initial and final karyotyping. The two estimates for each bull, the differences and the interval in years between karyotyping are in Table 2 . Percentages were converted to angles by arcsin transformation for analysis of variance (Snedecor \& Cochran, 1971). The difference of $1.2 \%$ between the means was not significant $\left(F_{1,13}=0.07 ; P>0.25\right)$. There was a highly significant difference among bulls $\left(\mathrm{F}_{13,13}=17.62 ; P<0.01\right)$.

Table 1. Mean percentage of XX lymphocytes in peripheral blood of chimaeric bulls $(H=$ Holstein; $\mathbf{G}=$ Guernsey; $\mathbf{A}=$ Ayrshire)

\begin{tabular}{|c|c|c|c|c|c|}
\hline \multirow[b]{2}{*}{ Bull } & \multicolumn{2}{|l|}{ A.I. bulls } & \multicolumn{3}{|c|}{ Experimental bulls } \\
\hline & $\begin{array}{c}\text { No. of } \\
\text { metaphases }\end{array}$ & $\% \mathrm{XX}$ & Bull & $\begin{array}{l}\text { No. of } \\
\text { metaphases }\end{array}$ & $\% X X$ \\
\hline $\begin{array}{ll}\text { H } & 1\end{array}$ & 216 & 5 & H 12 & 250 & 5 \\
\hline $\mathrm{H} 2$ & 231 & 24 & H 13 & 300 & 18 \\
\hline H 3 & 100 & 36 & H 14 & 241 & 27 \\
\hline $\mathrm{H} 4$ & 200 & 41 & H 15 & 352 & 29 \\
\hline H 5 & 100 & 43 & H 16 & 464 & 48 \\
\hline H 6 & 84 & 60 & H 17 & 106 & 52 \\
\hline $\mathrm{H} 7$ & 100 & 65 & H 18 & 258 & 81 \\
\hline H 8 & 137 & 71 & H 19 & 312 & 87 \\
\hline H 9 & 150 & 77 & H 20 & 200 & 95 \\
\hline H 10 & 267 & 85 & & & \\
\hline H 11 & 90 & 93 & & & \\
\hline G 1 & 58 & 33 & & & \\
\hline A 1 & 313 & 13 & & & \\
\hline
\end{tabular}

\section{Semen characteristics and reproductive performance}

Semen characteristics of ejaculates obtained at 1-2 years of age are summarized in Table 3. Seven attempts to collect semen from Bull 36 XX over a 9-week period failed because of the bull's poor libido and failure to serve the artificial vagina. No attempt was made to collect semen from Bull $43 \mathrm{XX}$, whose testes were globular and flaccid, and from Bull $71 \mathrm{XX}$, whose growth and physical condition were unsatisfactory. Semen from Bulls $13 \mathrm{XX}$ and $60 \mathrm{XX}$ did not meet A.I. standards and was not used for insemination; sperm concentration and motility were consistently low in the semen of Bull $13 \mathrm{XX}$ while the semen of Bull $60 \mathrm{XX}$, after staining with India ink, revealed $63 \%$ abnormal spermatozoa which included $22 \%$ with abaxial midpieces and $22 \%$ with cytoplasmic droplets. The semen of Bull $65 \mathrm{XX}$ froze poorly; during one season, $71 \%$ of his spermatozoa had abnormalities of the acrosomes. 
Table 2. Differences in percentage of XX lymphocytes in peripheral blood of chimaeric bulls at initial and final karyotyping

\begin{tabular}{|c|c|c|c|c|}
\hline \multirow[b]{2}{*}{ Bull* } & \multirow{2}{*}{$\begin{array}{c}\text { Interval } \\
\text { (years) }\end{array}$} & \multicolumn{3}{|c|}{$\%$ donor $\mathrm{XX}$ cells } \\
\hline & & Initial & Final & Difference \\
\hline \multicolumn{5}{|l|}{ A.I. } \\
\hline $5 \mathrm{XX}$ & 3.6 & 6 & 4 & -2 \\
\hline $24 \mathrm{XX}$ & $5 \cdot 2$ & 29 & 20 & -9 \\
\hline $41 X X$ & $3 \cdot 7$ & 52 & 29 & -23 \\
\hline $65 \mathrm{XX}$ & $3 \cdot 5$ & 63 & 68 & +5 \\
\hline $77 \mathrm{XX}$ & 4.4 & 68 & 82 & +14 \\
\hline $85 X X$ & $1 \cdot 5$ & 82 & 87 & +5 \\
\hline \multicolumn{5}{|c|}{ Experimental } \\
\hline $5 \mathrm{XX}$ & 5 & 14 & $2 \cdot 5$ & $-11 \cdot 5$ \\
\hline $18 \mathrm{XX}$ & 3 & 21 & 12 & -9 \\
\hline $27 \times X$ & 3 & 37 & 14 & -23 \\
\hline $29 \mathrm{XX}$ & 5 & 33 & 41 & +8 \\
\hline $48 \times X$ & 2 & 49 & 44 & -5 \\
\hline $52 \times X$ & $2 \cdot 2$ & 52 & 52 & 0 \\
\hline $81 \mathrm{XX}$ & 3 & 75 & 92 & +17 \\
\hline $87 \times X$ & 5 & 78 & 96 & +18 \\
\hline Means (a & nslated to \%) & $46 \cdot 3$ & $45 \cdot 1$ & $-1 \cdot 2$ \\
\hline
\end{tabular}

* This number was allocated to indicate the percentage of $\mathrm{XX}$ cells.

Table 3. Semen characteristics of A.I. chimaeric bulls during their sampling period at 1-2 years of age

\begin{tabular}{|c|c|c|c|c|c|c|}
\hline Bulls & $\begin{array}{l}\text { No. of } \\
\text { ejaculates }\end{array}$ & $\begin{array}{l}\text { Volume } \\
\text { (ml) }\end{array}$ & $\begin{array}{l}\text { Motile } \\
\text { sperm. } \\
\text { (\%) }\end{array}$ & $\begin{array}{l}\text { Sperm } \\
\text { conc./ml } \\
\left(\times 10^{6}\right)\end{array}$ & $\begin{array}{l}\text { Motile sperm./ } \\
\text { ejaculate } \\
\left(\times 10^{9}\right)\end{array}$ & $\begin{array}{c}\text { Ejaculates } \\
\text { discarded } \\
(\%)\end{array}$ \\
\hline $5 X X$ & 9 & 7.2 & 51 & 1216 & $4 \cdot 6$ & 11 \\
\hline $13 \mathrm{XX}$ & 14 & 7.2 & $47 \dagger$ & $552 \dagger$ & $1.9 \dagger$ & 100 \\
\hline $24 \mathrm{XX}$ & 9 & 4.4 & 54 & 1505 & 3.6 & 33 \\
\hline $36 \mathrm{XX}$ & $\mathbf{0}$ & No semen & & & & \\
\hline $41 \times X$ & 11 & 5.6 & 54 & 1013 & $3 \cdot 1 \dagger$ & \\
\hline $43 \mathrm{XX}$ & 0 & No semen & & & & \\
\hline $60 \mathrm{XX}$ & 15 & $5 \cdot 1$ & $17 \dagger$ & 1397 & $1.3 \dagger$ & $100 \ddagger$ \\
\hline $65 \times X$ & 10 & 5.5 & 56 & 2439 & 7.5 & \\
\hline $71 \mathrm{XX}$ & 0 & No semen & & & & \\
\hline $77 \mathrm{XX}$ & 10 & $6 \cdot 3$ & 55 & 1797 & $6 \cdot 5$ & \\
\hline $85 \mathrm{XX}$ & 32 & $8 \cdot 3$ & 58 & 1304 & $6 \cdot 3$ & \\
\hline $93 \times X$ & 11 & $4 \cdot 3$ & 53 & 1243 & $2 \cdot 8$ & 9 \\
\hline $\mathrm{XX} / \mathrm{XY}(n=9) \S$ & 121 & 6.0 & 49 & 1385 & $4 \cdot 2$ & $24^{* *}$ \\
\hline Controls $(n=9)$ & 98 & $5 \cdot 6$ & 55 & 1574 & 4.9 & 8 \\
\hline Differences & & +0.4 & -6 & -189 & -0.7 & +16 \\
\hline $\mathrm{XX} / \mathrm{XY}(n=12) q$ & 121 & $4 \cdot 5$ & $37^{*}$ & $1039^{*}$ & $3 \cdot 1^{*}$ & $24^{* *}$ \\
\hline Controls $(n=12)$ & 117 & $5 \cdot 7$ & 56 & 1665 & $5 \cdot 2$ & 7 \\
\hline Differences & & $-1 \cdot 2$ & -19 & -626 & $-2 \cdot 1$ & -17 \\
\hline
\end{tabular}

* These means significantly lower than the controls $(P<0.05)$.

** These percentages significantly higher than the controls $(P<0.01)$.

$\dagger$ These values are below those of control bulls.

$\ddagger$ Excessive number of abnormal spermatozoa.

$\S$ Means of the 9 bulls producing semen.

I Means of all 12 bulls. 
A comparison of the 9 semen-producing chimaeric bulls with their 9 controls revealed no significant differences between the means for sperm volume $\left(\mathrm{F}_{1,16}=0.61 ; P=0.45\right)$, motility (F $=1.90 ; P=0.19)$, concentration $(\mathrm{F}=0.77 ; P=0.39)$ and the number of motile spermatozoa per ejaculate $(\mathrm{F}=0.68 ; P=0.42)$. However, when the 3 impotent bulls and their 3 controls were included in the analyses, the differences were significant for motility, concentration and motile spermatozoa per ejaculate $\left(t_{(11)}=2.6, P<0.025\right)$. The 12 control bulls produced, on average, $2.1 \times 10^{9}$ motile spermatozoa per ejaculate more than did the 12 chimaeric bulls. Only $8(7 \%)$ of the 117 ejaculates of the controls were discarded, whereas $29(24 \%)$ of the 121 ejaculates of the chimaeric bulls were discarded. The difference was highly significant $\left(\chi^{2}=\right.$ $12.02 ; P<0.001)$.

During the period from birth to 10 years of age, $7(58 \cdot 3 \%)$ of the 12 chimaeric bulls were culled for poor reproductive performance (Table 4), whereas only 7 (5.4\%) of the 128 control bulls were culled, 3 with unsatisfactory semen and 4 with low fertility. The difference in culling rates was highly significant $\left(\chi^{2}=28.45 ; P<0.001\right)$.

Table 4. Reproductive performance and testicular pathology of $\mathrm{XX} / \mathrm{XY}$ bulls

\begin{tabular}{|c|c|c|c|c|}
\hline \multirow[b]{2}{*}{ Bull } & \multirow{2}{*}{$\begin{array}{c}\text { Age } \\
\text { (years) }\end{array}$} & \multicolumn{2}{|c|}{ Reproductive performance } & \multirow{2}{*}{$\begin{array}{c}\text { Testicular } \\
\text { lesions }\end{array}$} \\
\hline & & Rating & Defect & \\
\hline $77 \mathrm{XX}$ & 7 & Good & None & —* \\
\hline $41 \mathrm{XX}$ & 7 & Good & None & —* \\
\hline $5 X X$ & 6 & Good & None & SF-DT $\dagger$ \\
\hline $24 \mathrm{XX}$ & $7 \cdot 5$ & Good & None & SF-DT $\dagger$ \\
\hline $65 \mathrm{XX}$ & 6 & Fair & Sperm quality $\ddagger$ & SF-DT $\dagger$ \\
\hline $93 \mathrm{XX}$ & 10 & Poor & Sperm output; fertility & LF-DT \\
\hline $85 \mathrm{XX}$ & $8 \cdot 5$ & Poor & Sperm output & LF-DT \\
\hline $13 \mathrm{XX}$ & 3 & Poor & Sperm output & LF-DT \\
\hline $60 \times X$ & 2 & Poor & Abnormal spermatozoa & LF-DT \\
\hline $36 \mathrm{XX}$ & 1.5 & Poor & No libido, no semen & LF-DT \\
\hline $43 \mathrm{XX}$ & 1 & Poor & Testicular anomaly, no semen & LF-DT \\
\hline $71 \mathrm{XX}$ & 1 & Poor & Poor growth, no semen & LF-DT \\
\hline \multicolumn{5}{|c|}{ Experimental bulls (3-5 years) } \\
\hline \multirow{2}{*}{\multicolumn{4}{|c|}{$\begin{array}{l}5 \mathrm{XX} \text { and } 29 \mathrm{XX} \\
18 \mathrm{XX}, 27 \mathrm{XX}, 48 \mathrm{XX} \text { and } 87 \mathrm{XX}\end{array}$}} & LF-DT \\
\hline & & & & SF-DT \\
\hline
\end{tabular}

SF-DT, small foci of tubules deficient in germinal cells; LF-DT, large foci of tubules deficient in germinal cells with primordial germ cells and multinucleated giant cells in lumina.

* Bulls still in service.

$\dagger$ Bulls culled for genetic proof.

† Poor freezability and abnormal acrosomes as a 2-year-old.

There was an increase in sperm output by 6 of 7 chimaeric bulls in service at 6 years of age when compared with their sperm output as young bulls (means $=3.6 \times 10^{9}$ motile spermatozoa/ejaculate). There was a significant decrease $\left(1.81 \times 10^{9}\right.$ motile spermatozoa/ ejaculate) in sperm output of Bull $85 \mathrm{XX}\left(\mathrm{F}_{1,62}=7.87 ; P<0.01\right)$, and 18 of 32 successive ejaculates were discards $\left(\chi^{2}=22.34 ; P<0.001\right)$ with many abnormal spermatozoa which included $10-25 \%$ with abaxial midpieces as observed in semen of Bull $60 \mathrm{XX}$.

\section{Histopathology and cytogenetics of testes}

Histopathological examinations were made on testicular specimens from 16 chimaeric bulls (10 A.I. and 6 experimental) and 9 control bulls. All 16 chimaeric bulls had varied degrees of testicular degeneration as shown by tubules which were deficient in germinal cells (Table 4). The 
most advanced stages of degeneration were observed in the testes of Bull $60 \mathrm{XX}$ (Pl. 1, Fig. 1) and Bull $71 \mathrm{XX}$ (Pl. 1, Fig. 2). Bulls with good reproductive performance had only a few seminiferous tubules which were deficient in germinal cells (SF-DT), whereas those with poor reproductive performance had larger and more numerous focal areas of testicular degeneration (LF-DT). Many of these bulls also had perivascular and peritubular foci of lymphocytes. Four of the 12 randomly selected controls had LF-DT in at least one testis. Two of these 4 bulls had low sperm output but the reproductive fitness of the other 2, culled for unsatisfactory proofs, was not known. The incidence of LF-DT in the XX/XY bulls (70\%) was not significantly different from the $44.4 \%$ in the control bulls $\left(\chi^{2}=0.44 ; P>0.5\right)$.

Table 5. Meiotic chromosomes in testicular preparations from $\mathrm{XX} / \mathrm{XY}$ bulls

\begin{tabular}{|c|c|c|c|c|c|c|c|c|}
\hline \multirow[b]{3}{*}{ Bull } & \multirow{3}{*}{$\begin{array}{c}\text { Age } \\
\text { (years) }\end{array}$} & \multicolumn{4}{|c|}{ Spermatocytes } & \multirow{2}{*}{\multicolumn{3}{|c|}{ Spermatogonia }} \\
\hline & & \multicolumn{2}{|c|}{ Pachytene } & \multicolumn{2}{|c|}{ Diakinesis } & & & \\
\hline & & $\mathrm{XY}+$ & $X Y-$ & $X Y$ & $\mathrm{XX}(?)$ & $X Y$ & $\mathrm{XX}$ & Degen. \\
\hline \multicolumn{9}{|l|}{ A.I. } \\
\hline $5 X X$ & 6 & 13 & 0 & 1 & 0 & 0 & 0 & 0 \\
\hline $24 \mathrm{XX}$ & 8 & 0 & .0 & 33 & 4 & 2 & 0 & 1 \\
\hline $60 \times X$ & 2 & 275 & 51 & 4 & 1 & 3 & 0 & 21 \\
\hline $71 \mathrm{XX}$ & 1 & 55 & 3 & 0 & 0 & 0 & 0 & 3 \\
\hline $85 \times X$ & 9 & 21 & 4 & 0 & 0 & 0 & 0 & 13 \\
\hline \multicolumn{9}{|c|}{ Experimental } \\
\hline $5 \times X$ & 5 & 0 & 0 & 0 & 0 & 0 & 0 & 0 \\
\hline $18 X X$ & 3 & 0 & 0 & 0 & 0 & 0 & 0 & 0 \\
\hline $27 \times X$ & 3 & 8 & 0 & 2 & 2 & 0 & 0 & 0 \\
\hline $29 \mathrm{XX}$ & 5 & 119 & 6 & 19 & 1 & 1 & 0 & 0 \\
\hline $48 \times X$ & 3 & 22 & 2 & 5 & 0 & 0 & 0 & 0 \\
\hline $87 X X$ & 5 & 36 & 0 & 33 & 5 & 0 & 0 & 0 \\
\hline Totals & & 549 & 66 & 97 & 13 & 6 & 0 & 38 \\
\hline
\end{tabular}

$X Y+=X Y$ sex vesicle present; $X Y-=X Y$ sex vesicle absent; $X X($ ?) $=$ absence of typical end-toend association of $\mathrm{X}$ and $\mathrm{Y}$.

Meiotic preparations were made from testes of 5 A.I. and 6 experimental chimaeric bulls. The 769 observations are summarized in Table 5. Only a few XY, and no XX, spermatogonial metaphases were observed, partly due to the advanced testicular degeneration in many of these bulls. Of 110 spermatocytes in diakinesis, 97 showed the terminal association of the $\mathrm{X}$ and $\mathrm{Y}$ chromosomes and the 29 autosomal bivalents typical of the XY spermatocyte (Pl. 2, Fig. 3). The remaining 13, classified as $\mathrm{XX}($ ?), lacked the typical $\mathrm{XY}$ bivalent, but being contracted and condensed, they were most probably atypical XY bivalents (C. E. Ford, personal communication; Ford \& Evans, 1977). The typical heteropycnotic sex vesicle with the XY bivalent (Pl. 2, Fig. 4) was not observed in 66 pachytene nuclei (Pl. 2, Fig. 5). These, like the two reported by Short et al. (1969), may have been XX spermatocytes. On the other hand, they may be considered mid- to late pachytene in which the sex vesicle has disappeared, revealing the sex bivalent in ring-like forms (Pl. 2, Fig. 5).

\section{Fertility and progeny tests}

Semen of 8 A.I. chimaeric bulls was used for artificial insemination. Estimates of fertility are reported as 60 - to 90 -day non-return rates with deviations from corresponding 12 -month breed averages. The non-return rate for 30814 services to these 8 bulls was $70 \%$. The mean deviation from breed average was $-0.1 \%$ and not significant $\left(t_{7}=0.13 ; P>0.5\right)$. 
PLATE 1
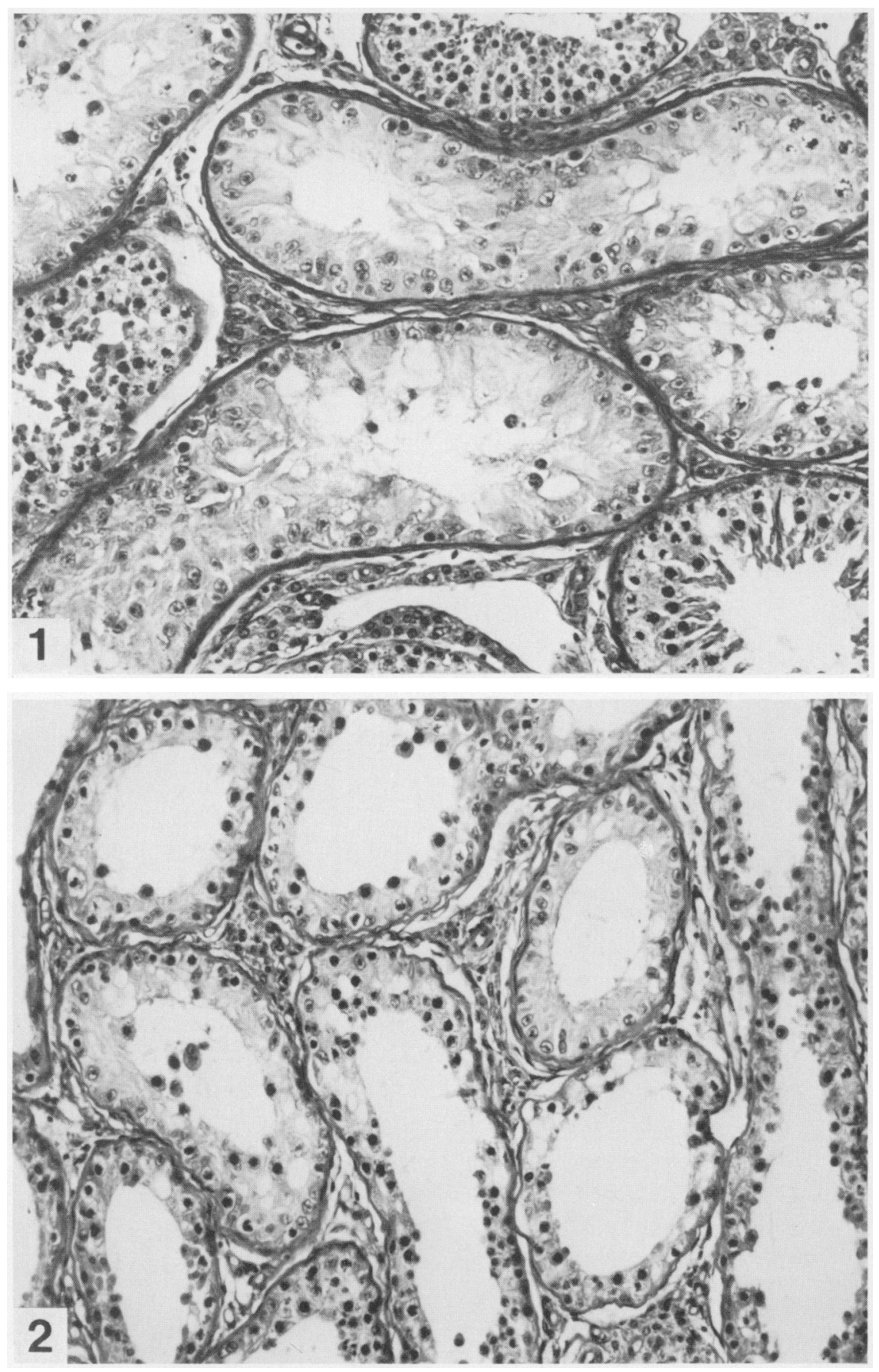

Fig. 1. Section of testis of Bull $60 \mathrm{XX}$ showing pycnotic germ cells and Sertoli cells. $\times 200$.

Fig. 2. Section of testis of Bull $71 \mathrm{XX}$ showing seminiferous tubules deficient in active germinal epithelium. $\times 200$.

(Facing p. 26) 



Fig. 3. An XY spermatocyte at diakinesis from testis of Bull $60 \mathrm{XX}$ showing the 29 autosomal bivalents and the end-to-end association of the $\mathrm{X}$ and $\mathrm{Y}$.

Fig. 4. A pachytene nucleus from the testis of Bull $60 \mathrm{XX}$ showing a typical $\mathrm{XY}$ sex vesicle, $\mathrm{SV}$.

Fig. 5. A pachytene nucleus from the testis of Bull $60 \mathrm{XX}$ showing absence of typical XY sex vesicle. Possible $\mathrm{X}-\mathrm{Y}$ bivalents (arrows). 
Sex ratio estimates were obtained on single-born offspring of 4 bulls (Table 6). Only the ratio for Bull $33 \mathrm{XX}$ was significantly different from a $1: 1$ ratio $\left(\chi^{2}=8.33 ; P<0.01\right)$. Differential haemolysis blood typing tests were made on Bull $85 \mathrm{XX}, 23$ of his daughters and their 23 dams. The results showed that $10-15 \%$ of his blood represented his own genotype, whereas $85-90 \%$ represented the genotype of his twin sister. The erythrocyte and lymphocyte mixtures were essentially identical for this bull, although this is not generally true for cattle chimaeras (W. $H$. Stone, R. G. Cragle, H. O. Dunn, A. F. McFee \& S. V. Rosser, unpublished data). Blood tests provided no evidence that Bull $85 \mathrm{XX}$ transmitted any of his twin sister's blood group genes to any of his 23 progeny. A blood test on Bull $33 \mathrm{XX}$ did not show erythrocyte chimaerism despite the clear chimaerism of the lymphocytes and tests on 3 of his daughters provided no evidence of abnormal transmission. There was no cytological evidence of germ cell chimaerism in any of the 4 bulls.

Table 6. Fertility and progeny sex ratios of A.I. chimaeric bulls

\begin{tabular}{|c|c|c|c|c|c|}
\hline \multirow[b]{2}{*}{ Bull } & \multirow[b]{2}{*}{$\begin{array}{c}\text { No. of first } \\
\text { services }\end{array}$} & \multicolumn{2}{|c|}{$60-90$ day } & \multirow{2}{*}{$\begin{array}{l}\text { Progeny } \\
\text { (no.) }\end{array}$} & \multirow[b]{2}{*}{$\begin{array}{l}\text { Sex ratio } \\
\% \mathrm{~F}: \% \mathrm{M}\end{array}$} \\
\hline & & $\%$ non-return & Deviation $\dagger^{\dagger}$ & & \\
\hline $5 X X$ & 402 & 66.9 & -0.1 & & \\
\hline $24 \mathrm{XX}$ & 13428 & $72 \cdot 2$ & $+3 \cdot 3$ & 126 & $48: 52$ \\
\hline $33 \times X$ & 1153 & $60 \cdot 0$ & $-5 \cdot 0$ & 48 & $71: 29^{*}$ \\
\hline $41 X X$ & 336 & $65 \cdot 8$ & -0.2 & & \\
\hline $65 \times X$ & 344 & 66.9 & -0.1 & & \\
\hline $77 \times X$ & 442 & 68.6 & $+2 \cdot 6$ & & \\
\hline $85 \mathrm{XX}$ & 3502 & $74 \cdot 9$ & -0.1 & 266 & $55: 45$ \\
\hline $93 \times X$ & 11207 & 67.0 & $-1 \cdot 3$ & 297 & $52: 48$ \\
\hline Total & 30814 & & & & \\
\hline Means & & $70 \cdot 0$ & $(-0 \cdot 1)$ & & \\
\hline
\end{tabular}

* Significantly different from a $1: 1$ ratio, $P<0 \cdot 01$.

$\uparrow$ Deviations from 12-month breed averages.

\section{Discussion}

This study provides further evidence that there is a marked reduction in the reproductive fitness of many bulls born co-twin with freemartins. Based on our sample of 12 chimaeric A.I. bulls and their 128 controls in one A.I. centre, there is a $58 \%$ chance that a chimaeric bull will be culled for poor reproductive performance in the first 10 years of his life, compared with only a $5 \%$ chance for a single-born non-chimaeric bull. As expected, there was no association between the percentage of $\mathrm{XX}$ donor blood cells and the reproductive fitness of a chimaeric bull. For example, Bull $77 \mathrm{XX}(23 \% \mathrm{XY})$ was superior to Bull $5 \mathrm{XX}(95 \% \mathrm{XY})$ in both sperm output and fertility, the poorest quality semen was produced by Bulls $13 \mathrm{XX}$ and $60 \mathrm{XX}$, while the fertility of Bulls $24 \mathrm{XX}, 77 \mathrm{XX}$ and $85 \mathrm{XX}$ was essentially equal. This is consistent with the report by Greene et al. (1977) who found that the XX : XY blood lymphocyte ratio was not related to the degree of masculinization of the freemartin reproductive organs. Similarly, W. H. Stone (unpublished) found that the degree of blood group chimaerism was not correlated with the severity of the freemartin condition.

Three chimaeras with anomalies of the reproductive tract (cryptorchidism and underdeveloped seminal vesicles and ampullae) have been reported (Abdel-Raouf, 1964; Gerneke, 1969; Short et al., 1969). In our study, one bull, No. 43 XX, had an anomaly of the reproductive tract (globular flaccid testes). One of the three chimaeras in the British Isles had poor semen quality (Stafford, 1972), but there were 7 chimaeras in our group which were culled for this 
reason. Two chimaeric bulls with low fertility were observed in the British Isles and Europe (Stafford, 1972; Cribiu \& Popescu, 1975; de Giovanni et al., 1975). Fertility of 7 of the 8 A.I. chimaeras listed in Table 6 was satisfactory; the Louisiana Guernsey, Bull 33 XX, was 5 percentage units below the breed average. Of the 7 chimaeras with satisfactory fertility, however, Bulls $85 \mathrm{XX}$ and $93 \mathrm{XX}$ were culled for low sperm output at 8.5 and 10 years of age, respectively. As mentioned above, normal breeding performance of chimaeric bulls has been reported. Most of the 34 bulls located in the British Isles or Europe were young bulls which may account for fewer reproductive problems. Nevertheless, there is no explanation for the marked difference in the sample described in this report and the good performance of many bulls in other locations. It seems very unlikely that there could be a breed or environmental effect. One can conclude that unlike the freemartins, which are sterile and have widely different degrees of virilization of the reproductive tract, the chimaeric bulls show a wide range in reproductive fitness but very little variation in the reproductive tract.

The aetiology of the reproductive failure and testicular degeneration in many of these bulls is only speculative. It may be associated with the embryonic and neonatal elimination of transplanted donor XX germ cells, which might be few or numerous (Ohno et al., 1962; Teplitz et al., 1967; Weiss \& Hoffmann, 1969) and the failure of the XY germ cells to repopulate certain portions of the tubules monopolized by the XX germ cells. Lymphocytic infiltration in the areas of testicular degeneration in the $\mathrm{XX} / \mathrm{XY}$ bulls with LF-DT lesions suggests a rejection phenomenon or autoimmune response. Testicular degeneration in 3 young $X Y / X Y$ chimaeric bulls from a group of 8 pairs of like-sexed chimaeric twins (K. McEntee \& H. O. Dunn, unpublished data) may be the result of autoimmune responses.

Our failure to find XX germ cells in testes of 11 chimaeric bulls, aged 1-9 years, accords with that of Ford \& Evans (1977) who found no XX germ cells in spermatogonia and primary spermatocytes of 7 chimaeric bulls, aged 44-46 weeks, and with that of Short et al. (1969) who found no XX germ cells in the testis of an 11-month-old chimaeric bull, with the exception of two possible $\mathrm{XX}$ spermatocytes. However, proving that no $\mathrm{XX}$ germ cells are present in either testis of an $\mathrm{XX} / \mathrm{XY}$ bull is a monumental task since the donor cells, if few in number, could be missed in the normal sampling procedure. The ease with which chimaerism can be overlooked in some cases was demonstrated by Dunn, McEntee \& Hansel (1970) who found only diploid XX cells in 600 metaphases from skin, blood and bone marrow of a $60, \mathrm{XX} / 90, \mathrm{XXY}$ bovine true hermaphrodite but detected many $\mathrm{Y}$-bearing triploid cells in other tissues. The conclusion by Weiss \& Hoffman (1969) that XX/XY chimaerism present in testes of a 2-month-old bull vanished by 18 months of age was based on only 72 cells and these from tissue culture.

Progeny tests on 2 sets of dizygotic twin bulls with erythrocyte chimaerism failed to detect transmission of donor genotypes to their offspring (Stone et al., 1960; Ross \& Thomas, 1978). Similarly, no evidence of abnormal transmission of blood group genes was detected in progeny of Bulls $85 \mathrm{XX}$ and $33 \mathrm{XX}$. No progeny tests were reported on the European chimaeric bull with $78 \%$ females $(P<0.001)$ in a progeny group of 148 (Cribiu \& Popescu, 1975; de Giovanni $e t$ al., 1975) or the chimaeric bull with $60 \%$ females $(P<0.025)$ in a progeny group of 168 (Lojda, 1972). Of the three chimaeric bulls with significant deviations in the percentages of female calves, two had low fertility (Bull $33 \mathrm{XX}$ and the de Giovanni bull) but the fertility of the Lojda bull was not reported. A New York A.I. Jersey bull, which was not karyotyped but was probably nonchimaeric, had $58 \%$ females in a progeny group of $168(P<0.05)$ which was the largest sexratio deviation in a study of 35.423 single births by mates of 111 sires (Foote, 1978).

As yet there appears to be no satisfactory evidence of germ cell chimaerism in the testes of chimaeric bulls. Short et al. (1969) suggested that XX germ cells are unable to undergo spermatogenesis when placed in a testicular environment. Ohno (1977) states that "the possession of more than one $\mathrm{X}$ chromosome is simply incompatible with further differentiation of testicular primordial germ cells to definitive spermatogonia". However, in the testis of sex reversed XX,Sxr/- male mice, aged 300 days, XO germ cells derived from XX primordial germ 
cells complete spermatogenesis and spermiogenesis forming $\mathrm{O}$ - and $\mathrm{X}$-bearing spermatozoa (Ohno, 1977). If similar events occurred in a chimaeric bull testis and the O-spermatozoa were not viable, an excess of $\mathrm{X}$-bearing spermatozoa could account for the over-abundance of daughters among progeny of certain chimaeric bulls.

We thank Dr S. Ohno for his advice and counsel during the years of this study and for his expert comments on the manuscript; Dr C. E. Ford for interpretation of certain atypical XY bivalents; Dr N. S. Fechheimer for karyotype data on 4 of the young bulls; Dr D. L. VanVleck for his assistance on the computer analysis of variance; and Dr R. H. Foote for his comments on the manuscript. We gratefully acknowledge the Eastern A.I. Cooperative and the Louisiana Dairy Herd Improvement Centre for specimens and pertinent sire data.

\section{References}

Abdel-Raouf, M. (1964) Pseudohermaphroditism in cattle. J. vet. Sci. U.A.R. 1, 1-8.

Coulter, G.H., Larson, L.L. \& Foote, R.H. (1975) Effect of age on testicular growth and consistency of Holstein and Angus bulls. J. Anim. Sci. 41, 13831389.

Cribiu, E.P. \& Popescu, C.P. (1975) Sur la frequence du chimerisme leucocytaire $\mathrm{XX} / \mathrm{XY}$ parmi les Taureaux d'insemination. Proc. 2nd Eur. Colloq. Cytogenetics, Giessen, pp. 204-211.

de Giovanni, A., Popescu, C.P. \& Succi, G. (1975) Premiere etude cytogenetique dans un centre Italien d'insemination artificielle. Annls Genet. Sel. anim. 7, $311-315$.

Dunn, H.O., Lein, D.H. \& Kenney, R.M. (1967) The cytological sex of a bovine anidian (amorphous) twin monster. Cytogenetics 6, 412-419.

Dunn, H.O., Kenney, R.M., Stone, W.H. \& Bendel, S. (1968) Cytogenetic and reproductive studies of $\mathrm{XX} / \mathrm{XY}$ chimeric twin bulls. Proc. 6th Int. Congr. Anim. Reprod. \& A.I., Paris 2, 877-879.

Dunn, H.O., McEntee, K. \& Hansel, W. (1970) Diploidtriploid chimerism in a bovine true hermaphrodite. Cytogenetics 9, 245-259.

Evans, E.P., Breckon, G. \& Ford, C.E. (1964) An airdrying method for meiotic preparations from mammalian testes. Cytogenetics 3, 289-294.

Foote, R.H. (1978) Reproductive performance and problems in New York dairy herds. N.Y. St. Coll. Agr. \& Life Sci., Search 8, 1-18.

Ford, C.E. \& Evans, E.P. (1977) Cytogenetic observations on $\mathrm{XX} / \mathrm{XY}$ chimaeras and reassessment of the evidence for germ cell chimaerism in heterosexual twin cattle and marmosets. J. Reprod. Fert. 49, 2533.

Gerneke, W.H. (1969) Sterility in a bull, co-twin to a freemartin. J. S. Afr. vet. med. Ass. 40, 279-283.

Greene, W.A., Dunn, H.O. \& Foote, R.H. (1977) Sexchromosome ratios in cattle and their relationship to reproductive development in freemartins. Cytogenet. Cell Genet. 18, 97-105.

Gustavsson, 1. (1977) Fertility of sires as dizygotic twins and sex ratio in their progeny groups. Annls Genet. Sel. anim. 9, 531.
Hansen, K.M. (1968) The spermiogram in a 60,XX/60,XY Jersey bull. Proc. 6th Int. Congr. Anim. Reprod. \& A.I., Paris 2, 141.

Jost, A., Vigier, B. \& Prepin, J. (1972) Freemartins in cattle: the first steps of sexual organogenesis. $J$. Reprod. Fert. 29, 349-379.

Lojda, L. (1972) Chromosomal chimerism of the sire as a cause of the shift in sex ratio in his offspring. Proc. 7th Int. Cong. Anim. Reprod. \& A.I., Munich 2, 1110-1113.

McSparrin, B.H. \& Patrick, T.E. (1967) Relationships among 60-90 day non-returns, diagnosed pregnancies, and actual calving of cows bred artificially. $J$. Dairy Sci. 50, 612.

Ohno, S. (1965) Direct handling of germ cells. In Human Chromosome Methodology, pp. 75-90. Ed. J. J. Yunis. Academic Press, New York.

Ohno, S. (1969) The problem of the bovine freemartin. $J$. Reprod. Fert., Suppl. 7, 53-61.

Ohno, S. (1977) Control of meiotic processes. In The Testis in Normal and Infertile Men, pp. 1-8. Eds P. Troen \& H. R. Nankin. Raven Press, New York.

Ohno, S., Trujillo, J.M., Stenius, C., Christian, L.C. \& Teplitz, R.L. (1962) Possible germ cell chimeras among newborn dizygotic twin calves (Bos taurus). Cytogenetics 1, 258-265.

Ohno, S., Christian, L.C., Wachtel, S.S. \& Koo, G.C. (1976) Hormone-like role of $\mathrm{H}-\mathrm{Y}$ antigen in bovine freemartin gonad. Nature, Lond. 261, 597-599.

Pierrepoint, C.G., Stewart, J.S.S. \& Rack, J. (1969) Patterns of steroid biosynthesis in the gonads of freemartins and their male co-twins. J. Reprod. Fert., Suppl. 7, 63-72.

Pollock, D.L. (1975) Sex chromosome chimaerism in Friesian bulls. Proc. 2nd Eur. Colloq. Cytogenetics, Giessen, pp. 199-203.

Ross, D. S. \& Thomas, W.J. (1978) The possibility of germ cell chimaerism in dizygotic twin bulls. Anim. Blood Grps biochem. Genet. 9, 3-8.

Short, R.V., Smith, J., Mann, T., Evans, E.P., Hallet, J., Fryer, A. \& Hamerton, J.L. (1969) Cytogenetic and endocrine studies of a freemartin heifer and its bull co-twin. Cytogenetics 8, 369-388.

Snedecor, G.W. \& Cochran, W.G. (1971) Statistical 
Methods, 6th edn. Iowa State University Press, Ames, Iowa.

Stafford, M.J. (1972) The fertility of bulls born co-twin to heifers. Vet. Rec. 90, 146-148.

Stone, W.H., Berman, D.T., Tyler, W.J. \& Irwin, M.R. (1960) Blood types of the progeny of a pair of cattle twins showing erythrocyte mosaicism. J. Hered. 51, 136-140.
Teplitz, R.L., Moon, Y.S. \& Basrur, P.K. (1967) Further studies of chimerism in heterosexual cattle twins. Chromosoma 22, 202-209.

Weiss, E. \& Hoffiman, R. (1969) Eliminierung der XXzellen im hoden heterosexueller rinderzwillinge mit $\mathrm{XX} / \mathrm{XY}$-chimerismus. Cytogenetics 8, 68-73.

Received 10 October 1978 